\title{
Correction to: Effects of Father-Adolescent and Mother-Adolescent Relationships on Depressive Symptoms among Chinese Early Adolescents
}

\author{
Qiongwen Zhang ${ }^{1} \cdot$ Yangu Pan ${ }^{1} \cdot$ Yanghong Chen ${ }^{2} \cdot$ Wei Liu ${ }^{3} \cdot$ Li Wang $^{1}$. \\ Jason A. Jean ${ }^{1}$
}

Published online: 17 November 2021

(c) The Author(s) 2021

\section{Correction to: Applied Research in Quality of Life https://doi.org/10.1007/s11482-021-09997-5}

The article "Effects of Father-Adolescent and Mother-Adolescent Relationships on Depressive Symptoms among Chinese Early Adolescents", written by Qiongwen Zhang, Yangu Pan, Yanghong Chen, Wei Liu, Li Wang, and Jason A. Jean, was originally published electronically on the publisher's internet portal on 20 September 2021 without open access. With the author(s)' decision to opt for Open Choice the copyright of the article changed on 10 October 2021 to (C) The Author(s) 2021 and the article is forthwith distributed under a Creative Commons Attribution 4.0 International License, which permits use, sharing, adaptation, distribution and reproduction in any medium or format, as long as you give appropriate credit to the original author(s) and the source, provide a link to the Creative Commons licence, and indicate if changes were made. The images or other third party material in this article are included in the article's Creative Commons licence, unless indicated otherwise in a credit line to the material. If material is not included in the article's Creative Commons licence and your intended use is not permitted by statutory regulation or exceeds the permitted use, you will need to obtain permission directly from the copyright holder. To view a copy of this licence, visit http://creativecommons.org/licenses/by/4.0.

The original article has been corrected.

Open Access This article is licensed under a Creative Commons Attribution 4.0 International License, which permits use, sharing, adaptation, distribution and reproduction in any medium or format, as long as you give appropriate credit to the original author(s) and the source, provide a link to the Creative

The online version of the original article can be found at https://doi.org/10.1007/s11482-021-09997-5

Yangu Pan

panyg@swufe.edu.cn

1 Research Institute of Social Development, Southwestern University of Finance and Economics, No. 555, Liutai Road, Chengdu 611130, Wenjiang District, China

2 School of Economics, Southwestern University of Finance and Economics, Chengdu, China

3 Institute of Sociology, Sichuan Academy of Social Sciences, Chengdu, China 
Commons licence, and indicate if changes were made. The images or other third party material in this article are included in the article's Creative Commons licence, unless indicated otherwise in a credit line to the material. If material is not included in the article's Creative Commons licence and your intended use is not permitted by statutory regulation or exceeds the permitted use, you will need to obtain permission directly from the copyright holder. To view a copy of this licence, visit http://creativecommons.org/ licenses/by/4.0/.

Publisher's Note Springer Nature remains neutral with regard to jurisdictional claims in published maps and institutional affiliations. 